\title{
Evaluation of the physicochemical and textural properties of pomelo fruit following storage
}

\author{
Panmanas SIRISOMBOON*, Ravipat LAPCHAREONSUK
}

Agric. Eng. Curric.,

School Mech. Eng., Fac. Eng., King Mongkut's Inst. Technol. Ladkrabang, Bangkok 10520, Thailand,

kspanman@kmitl.ac.th
${ }^{*}$ Correspondence and reprints

Received 2 September 2011 Accepted 16 January 2012

Fruits, 2012, vol. 67, p. 399-413 (C) 2012 Cirad/EDP Sciences All rights reserved DOI: 10.1051/fruits/2012034 www.fruits-journal.org

RESUMEN ESPAÑOL, p. 413

\section{Evaluation of the physicochemical and textural properties of pomelo fruit following storage.}

Abstract - Introduction. Because of the long transportation times and storage durations that are often experienced, it is important to understand how pomelo properties change over time; that will be indicative of how long samples can be stored before they drop below acceptable quality limits. As no information is available regarding storage of pomelo fruit in the literature, the goal of our work was to study the change in pomelo physicochemical and textural properties following storage over a period of approximately 4 months. Materials and methods. The changes in physical, chemical and textural properties of commercial pomelo fruit were extensively evaluated over the course of a 4-month storage period. The correlation among physical, color, chemical and textural properties were also assessed. Results. Color properties $\left(L^{*}, a^{*}, b^{*}\right)$ changed significantly with storage; however, they did not change much during the initial 45 days of storage. The change in soluble solids content (SSC), acidity (A) and the [(SSC) / (A)] ratio suggested that pomelo fruit should not be stored for more than 75 days. Crucially, our study demonstrates that the $a^{*}$ parameter (greenness, $R=-0.556$ ) correlates best with the chemical property the $[$ (SSC) / (A)] ratio, which is a recognized measurement of the consumer acceptability of citrus fruit. This means that measuring $a^{*}$ is a non-destructive way of monitoring the taste characteristics of pomelos in storage. This property also correlated well with the average firmness of the fruit and with the flesh texture. Conclusion. This fundamental information on the pomelo fruit could prove useful in the physical handling and processing of the fruit by breeders and postharvest technologists as well as distributors, market agents, importers and exporters.

Thailand / Citrus grandis / fruits / pomelos / storage / physicochemical properties / texture / rheological properties

\section{Évaluation des propriétés physico-chimiques et de texture de chadecs au cours de leur stockage.}

Résumé - Introduction. En raison des longueurs de transport et de stockage souvent constatées, il serait important de comprendre comment les propriétés des chadecs évoluent au fil du temps; cette information serait utile pour évaluer combien de temps les échantillons peuvent être stockés tout en conservant une qualité gustative acceptable. Faute d'informations disponibles dans la littérature sur le stockage du chadec, nous avons étudié la variation des propriétés physico-chimiques et de la texture de ce fruit sur une période de stockage de 4 mois environ. Matériel et méthodes. Le changement des composantes de propriétés physiques, chimiques et de texture de chadecs commerciaux ont été évalués pendant 4 mois de stockage. Les corrélations entre ces diverses composantes ont également été évaluées. Résultats. Les paramètres de couleur $\left(L^{*}, a^{*}, b^{*}\right)$ ont varié de manière significative pendant le stockage, mais ils n'ont pas beaucoup changé au cours des 45 premiers jours d'entreposage. Le changement de la teneur en solides solubles (SSC), de l'acidité (A) et du rapport [(SSC)/(A)] a suggéré que les chadecs ne devraient pas être stockés plus de 75 jours. Fondamentalement, notre étude a démontré que le paramètre $a^{*}$ (verdissement, $R=-0,556$ ) était le mieux corrélé avec la propriété chimique "rapport [(SSC) / (A)] " qui est une mesure reconnue d'acceptabilité des fruits par le consommateur d'agrumes. Cela signifie que la mesure de $a^{*}$ serait une technique non destructive permettant de contrôler les caractéristiques du goût des chadecs pendant leur stockage. Ce paramètre est également bien corrélé avec la fermeté moyenne du fruit et la texture de sa chair. Conclusion. Cette information fondamentale sur le chadec pourrait s'avérer utile aux sélectionneurs, techniciens, ainsi qu'aux distributeurs, commerciaux, importateurs et exportateurs lors de la manutention et du traitement industriel des fruits après leur récolte.

Thailande / Citrus grandis / fruits / chadec / stockage / propriété physicochimique / texture / propriété rhéologique 


\section{Introduction}

Pomelo (Citrus maxima or Citrus grandis) is one of the largest citrus fruits. The fruit flesh is normally consumed rather than processing it into a juice and is renowned for its good flavor and juicy texture. In addition, it was reported that the flesh of pomelo contains important nutrients including vitamin C, para-insulin, potassium, pectin, natural folic acid and chromium ${ }^{1}$.

The pomelo fruit is particularly popular throughout Asia, Europe and America because of its desirable taste characteristics. Thailand, for example, currently exports pomelo to countries in Asia (China, Hong Kong, Singapore, Malaysia, Indonesia, Laos, Vietnam and Myanmar), Western Asia (Iran, United Arab Emirates and Saudi Arabia) and Europe (Norway, the Netherlands, the United Kingdom and Switzerland), as well as the United States and Canada. In 2010, the exported quantity was 12,149,126 kg $(129,464,307 \text { Baht/4.3 million US\$ })^{2}$.

There have been several studies that have investigated the changes in physicochemical properties that occur during fruit maturation. These studies have been performed on a variety of fruits such as the Granny Smith apple [1], Hass avocado [2], sunberry [3] and pomegranate [4]; before and after processing such as dabai fruit [5], and during storage such as Granny Smith apple [1], Hass avocado [2], and Palmer mangoes [6]. For citrus fruit, the Florida grapefruit [7], mandarin [8], Fortune mandarins [9], Navel oranges, Star Ruby grapefruit and Satsuma mandarins [10] during storage, and unripe oranges during processing [11], were studied. Fruit skin color, size, shape, weight, mesocarp thickness, firmness, soluble solids concentration,

1 Alice White Green, The nutritional value of pomelo, http://EzineArticles.com/ 5647080, consulted on 11 August 2011.

2 Thai Customs Department, Import-Export Statistics, http://www.customs.go.th/Statistic/StatisticResult2550.jsp?page $=1 \&$ statType $=$ export\&month $=12 \&$ year $=2010 \&$ product CodeCheck $=$ Y\&productCode $=08054000001$ \&countryCheck=null\&country $=$, consulted on 11 August 2011.
$\mathrm{pH}$, titratable acidity, organic acids, respiration production rate and ethylene concentration were investigated in these studies.

The pomelo fruit has a thick rind (thin flavedo and thick albedo) which protects the flesh inside from applied forces and water evaporation [12]. This also helps in the handling of the pomelo fruit during transportation. However, the properties of this fruit can differ significantly depending on the time the fruit is harvested or the length of storage. Thus it is important to understand how the external and internal properties of pomelo change since this can have implications for fruit export, as transportation and storage can be significant in duration. The external and internal textural properties of a fruit are important parameters that can influence the choice of consumers. Puncture and plate compression tests, while relatively simple, and routine, are classical tests that can provide extensive information regarding the textural properties of the items under investigation. The plate compression test and/or the puncture test have been used to study textural properties of Tarocco orange [13], pear [14-16], mango [17, 18] and cherimoya fruit [19] in the past. Due to the long transportation times and storage durations that are often experienced, it is important that one fully understands how these properties change over time since this will be indicative of how long samples can be stored before they drop below acceptable quality limits. However, at present there is no information available regarding storage of the pomelo fruit in the literature. Therefore, the goal of our work was to study the change in these physicochemical and textural properties of this fruit following storage over a period of approximately 4 months. This data is useful information for breeders and postharvest technologists as well as distributors, market agents, importers and exporters of pomelos.

\section{Materials and methods}

We studied the physical properties of pomelos, including fruit size, weight, volume and apparent density along with the textural properties of the fruit and rind, given that 
they have implications for fruit handling and the design of processing equipment. In addition, the color properties of the rind, the texture of the internal flesh and certain other internal characteristics, such as the soluble solids content, acidity and the ratio of soluble solids to acidity, which is a measurement of the quality or flavor index of citrus fruits, were also assessed.

\subsection{Sampling}

Pomelos (Citrus maxima or Citrus grandis cv. Kao Num Peung) were harvested from a commercial orchard located in Nakhon Pathom province, Thailand. Fruits were randomly collected 200 days after initial blooming, as is usual for commercial harvesting practice. The pomelos were then waxed (Nature Bright, Israel) using a line waxing machine: washing of fruit using water, drying using cloth surface rollers, spraying of wax over the fruit, and the final drying step in a hot air tunnel. The fruits were then transported to King Mongkut's Institute of Technology Ladkrabang, Bangkok, Thailand, and stored in a cooled room at $10{ }^{\circ} \mathrm{C}$ with a relative humidity of $70 \%$. Storage duration times of $(0,15,30,45,60,75,90,105$ and 120) days were considered. For experimental assessment, twenty fruit samples were randomly taken from storage at each time interval.

The rind of pomelo consists of the flavedo, which is a green color with oil glands spotted all over the fruit peel, and the albedo. The latter is spongy in texture and white in color. There are several segments (8-9) containing juice sacs and each is covered with a tough skin called a lamella. At the center of the fruit, there is a core which is hollow when ripe. Seeds are generally located in the individual segments, close to the core.

\subsection{Physical properties and color}

The physical properties, including the average diameter, geometric mean diameter, weight, volume, apparent density, and color properties, including CIE lightness $\left(L^{*}\right)$, red- green value $\left(a^{*}\right)$ and blue-yellow value $\left(b^{*}\right)$ of all fruit, were measured.

\subsubsection{Average diameter, geometric mean diameter and weight}

For each fruit, the height (a), equatorial width perpendicular to $a$ (b) and breadth perpendicular to $a$ and $b$ (c) were determined using a digital Vernier height gauge (Mitutoyo, H6-18"P, with a 0.02-mm resolution) with some modification for measuring the dimensions practically. The average diameter (AVD) and the geometric mean diameter (GMD) were given by: AVD $=[(a+b+c) /$ 3] and $\mathrm{GMD}=(a \times b \times c)^{1 / 3}$.

Each fruit was weighed using a digital electric balance (ARC 120, OHAUS, max weight $3,000 \mathrm{~g}$ with a $0.01 \mathrm{~g}$ resolution).

\subsubsection{Volume and apparent density}

The methodology described by Mohsenin [20] and used by Sirisomboon et al. [21] was used to determine the volume of the pomelo fruit. The mass of each pomelo fruit was weighed in the air as described above; it was then weighed in reverse osmosis water in a bucket with a platform electric balance (AFM, UWE amx, maximum weight of $60 \mathrm{~kg}$ with $0.01 \mathrm{~kg}$ resolution). The volume ( $\mathrm{V}$ in $\mathrm{m}^{3}$ ) of the fruit was calculated using the principle of buoyant force: $\mathrm{V}=\left(\mathrm{m}_{\mathrm{W}} / \rho_{\mathrm{W}}\right)$, where $\mathrm{m}_{\mathrm{w}}$ is the weight of displaced water, i.e., fruit mass weighed (in $\mathrm{kg}$ ) in water, and $\rho_{\mathrm{W}}$ is the density of water (approximately $1,000 \mathrm{~kg} \cdot \mathrm{m}^{-3}$ ).

The apparent density $\rho_{\mathrm{a}}\left(\right.$ in $\mathrm{kg} \cdot \mathrm{m}^{-3}$ ) is defined as the weight of the individual fruit in air $\left(\mathrm{m}_{\mathrm{a}}\right.$ in $\left.\mathrm{kg}\right)$ divided by its volume: $\rho_{\mathrm{a}}=\left(\mathrm{m}_{\mathrm{a}} / \mathrm{V}\right)$.

\subsubsection{Color}

The CIE $L^{*} a^{*} b^{*}$ was determined at five positions $\left(72^{\circ}\right.$ apart) at the equatorial part of the pomelo fruit using a spectrophotometer (MiniScan XE Plus 45/0 LAV, Hunter Associates Laboratory Inc., Reston, USA). A D65 illuminant with a $2^{\circ}$ observer angle was used. Measurements were performed in triplicate at each position, and then they were averaged. 


\subsection{Texture analysis}

Following the removal of the pomelos from storage, fruit were kept at $25^{\circ} \mathrm{C}$ for a period of 24 hours. Their textural properties were then measured using the puncture and plate compression tests, consecutively, with a texture analyzer (Stable Micro System model TA HD Plus, London, UK). The effect from the former test was considered to be negligible. The two tests were performed on the fruit at positions at the equatorial part of the fruit $144^{\circ}$ clockwise apart. This was because the fruit was considered to be divided into five sections $72^{\circ}$ apart.

In the puncture test, the probe must penetrate the fruit, passing through the peel and into the flesh. It is a measurement of the strength of the peel and flesh, separately, at the point of puncture. It is different from the plate compression test, which is a measurement of the impact of compression of the fruit as a whole.

For the puncture test, a stainless steel plunger with a flat end (3-mm diameter) attached to the load cell (490.5 N) was used to penetrate the fruit up to $50 \mathrm{~mm}$ depth with a penetrating speed of $0.2 \mathrm{~mm} \cdot \mathrm{s}^{-1}$ [12].

The method used for the plate compression test was as follows: a flat aluminum plate (100-mm diameter) was attached to the load cell $(490.5 \mathrm{~N})$ and was used to compress the pomelo at a deformation speed of $0.2 \mathrm{~mm} \cdot \mathrm{s}^{-1}$. Relaxation tests were performed at a maximum compression force of $40 \mathrm{~N}$, with a 30-s relaxation time. The decline in force was recorded [12].

The computer software "Texture Exponent 32 version 4,0,3,0" (Stable Micro Systems, London, UK) was used to control the texture analyzer, to record the force, deformation and time, and to calculate the texture parameters.

\subsection{Chemical properties}

The soluble solids content obtained from the juice of each fruit was measured using a digital refractometer (Atago, Pocket PAL-1, Japan) and expressed in \%Brix. This was done at least in duplicate per sample. The titratable acidity was subsequently assessed using $50 \mathrm{~mL}$ juice contained in a 100-mL beaker according to the AOAC method [22]. The sample was titrated with $0.1 \mathrm{M} \mathrm{NaOH}$ to $\mathrm{pH} 8.1 \pm 0.02$, with monitoring being performed using an electrode pH meter (HANNA, HI 8521, Italy). This was repeated twice per sample.

\subsection{Statistical analysis}

The means and standard deviations of all properties were calculated. Means of the experimental data were compared by the Least Significant Different (LSD) test at a 95\% confidence interval. The correlation coefficients among the properties were calculated using Microsoft Excel and their significance values were calculated using a table of significant values of $r$ and $R$ [23].

\section{Results and discussions}

\subsection{Change in physical and color properties over time}

Our results regarding the change in physical and color properties of pomelo fruit extracted from storage at different times over 120 days showed that the color $\left(L^{*}, a^{*}\right.$, $\left.b^{*}\right)$ changed most significantly with storage (table I). The lightness $\left(L^{*}\right)$ increased, greenness $\left(-a^{*}\right)$ decreased and the yellowness $\left(b^{*}\right)$ increased with storage duration. However, the color did not change dramatically during the initial 45 days of storage.

On the other hand, the apparent density did not change significantly over time, while fruit size, weight and volume changed slightly (table I). This observation might be due to the fact that the fruit were waxed before storage since, in this condition, it is difficult for water to evaporate from the fruit.

\subsection{Change in chemical properties}

Our results regarding the change observed in the chemical properties of pomelo juice during storage showed that the soluble solids content increased significantly up until 75 days of storage and decreased subsequently (table II). Since the weight of fruit 


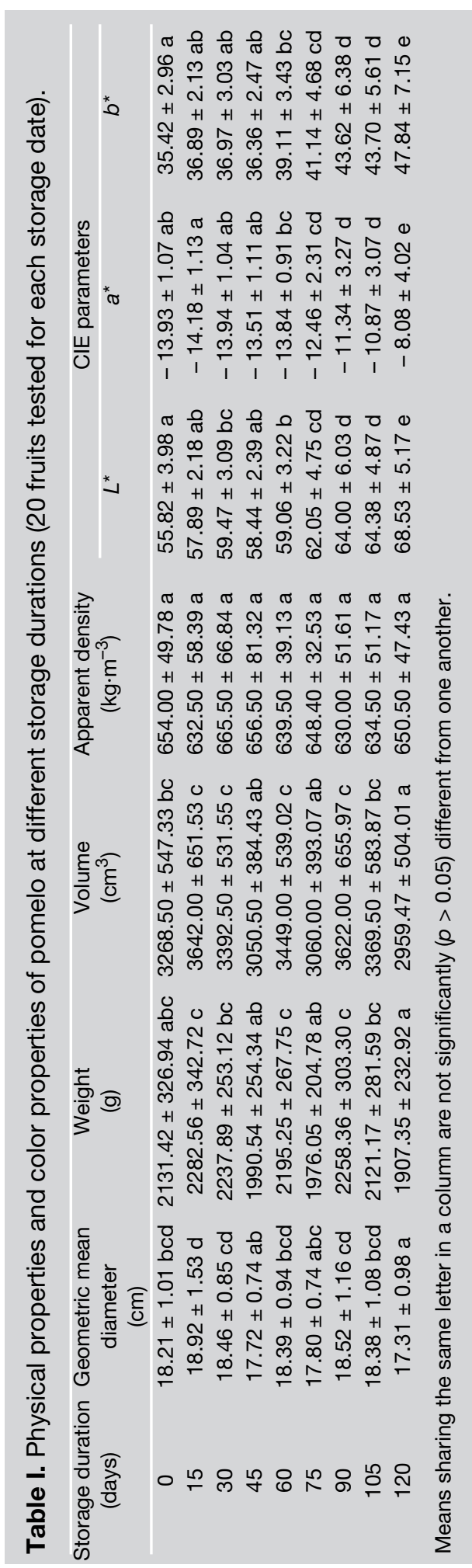


Table II. Chemical properties of juice of pomelo at different fruit storage durations.

$\begin{array}{cccc}\begin{array}{c}\text { Storage } \\ \text { duration } \\ \text { (days) }\end{array} & \begin{array}{c}\text { Soluble solids } \\ \text { content } \\ \text { (\%Brix) }\end{array} & \text { Acidity } & \begin{array}{c}\text { [Soluble solids } \\ \text { content / Acidity] }\end{array} \\ 0 & 9.0 \pm 0.9 \mathrm{a} & 0.548 \pm 0.101 \mathrm{a} & 17.0 \pm 3.0 \mathrm{a} \\ 15 & 9.0 \pm 0.6 \mathrm{a} & 0.565 \pm 0.055 \mathrm{ab} & 16.0 \pm 1.9 \mathrm{ab} \\ 30 & 9.9 \pm 0.6 \mathrm{~b} & 0.540 \pm 0.048 \mathrm{a} & 18.5 \pm 1.5 \mathrm{acd} \\ 45 & 10.0 \pm 0.8 \mathrm{~b} & 0.557 \pm 0.057 \mathrm{a} & 18.2 \pm 2.6 \mathrm{ac} \\ 60 & 10.1 \pm 0.6 \mathrm{~b} & 0.531 \pm 0.101 \mathrm{a} & 20.2 \pm 4.2 \mathrm{~d} \\ 75 & 10.3 \pm 0.7 \mathrm{bc} & 0.533 \pm 0.057 \mathrm{a} & 19.5 \pm 2.2 \mathrm{~cd} \\ 90 & 9.9 \pm 0.6 \mathrm{~b} & 0.516 \pm 0.062 \mathrm{ac} & 19.5 \pm 2.3 \mathrm{~cd} \\ 105 & 9.8 \pm 0.8 \mathrm{bd} & 0.454 \pm 0.077 \mathrm{~d} & 22.2 \pm 3.5 \mathrm{e} \\ 120 & 9.8 \pm 0.7 \mathrm{bd} & 0.419 \pm 0.058 \mathrm{~d} & 24.2 \pm 4.8 \mathrm{f}\end{array}$

Means sharing the same letter in a column are not significantly $(p>0.05)$ different from one another.
Figure 1.

Average force-time curve of the plate compression test of pomelo at different storage durations. Samples of 1820 fruit studied for each storage duration. changed only slightly, and since evaporation from the fruit was limited, the change in soluble solids content is likely to be a result of a biochemical change in the flesh.

The acidity of the juice remained constant up until 75 days of storage and reduced subsequently (table II). Therefore, the [soluble solids content / acidity] ratio was essentially constant during 90 days of storage with a range of 17.0-20.2, but increased after this time. This ratio is an accepted consumer acceptability benchmark, as a ratio of 10 to 16 is considered to be an acceptable value for citrus [24]. Nevertheless, this range is lower than that of some other citrus fruits

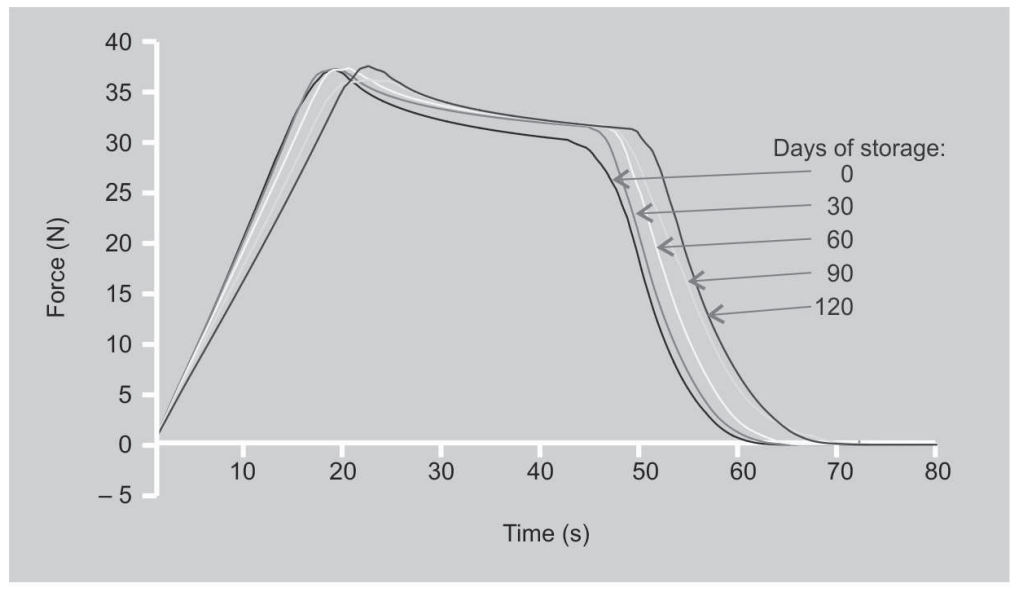

after sensory tests in more recent times. A study by Campbell et al. [25] on the Owari mandarin suggested that an acceptable value corresponded to 15 or more. At (105 and 120) days, the ratio for pomelo reached 22.2 and 24.2, respectively.

\subsection{Changes in textural properties measured by the plate compression test}

The average force-time curves obtained using the plate compression test on pomelos at different storage durations indicated that the maximum force was not exactly at $40 \mathrm{~N}$ in the average curve (figure 1), due to the fact that the average was taken from all fruits at each storage time, and the time taken to reach $40 \mathrm{~N}$ was not the same for each fruit. From the slope of the curve before the point corresponding to the maximum force, which is indicative of the average firmness of the fruit, it could be seen that the firmness had obviously decreased with time.

After different storage periods using the plate compression test, it could be observed that the firmness of the whole fruit dropped over time (figures $2 a, 2 b$ ). The energy absorption associated with permanent deformation increased during storage ( $f i g-$ ures 2c). The energy absorption is based on the hysteresis area of force and the deformation curve. When it returns, the curve cannot reach the origin; permanent deformation is caused and the energy absorption increased. Also, the permanent deformation is caused by destruction and flow of the internal fruit cell. The deformation ratio, which indicates the strain on the fruit, increased slightly over time. It was observed that the fruit would deform between 1.9\% and $2.4 \%$ under a force $(40 \mathrm{~N})$ over the course of the study. Moreover, the degree of elasticity increased slightly (0.666 to 0.719 ) following 30 days of storage, and gradually decreased after that (0.719 to 0.678 ) (figures $2 d$ ). The degree of elasticity indicates the ability of the fruit to recover from deformation once an applied force is removed. If the degree of elasticity is 0.666 , then the fruit can recover from $66.6 \%$ of the total deformation. This means that the 


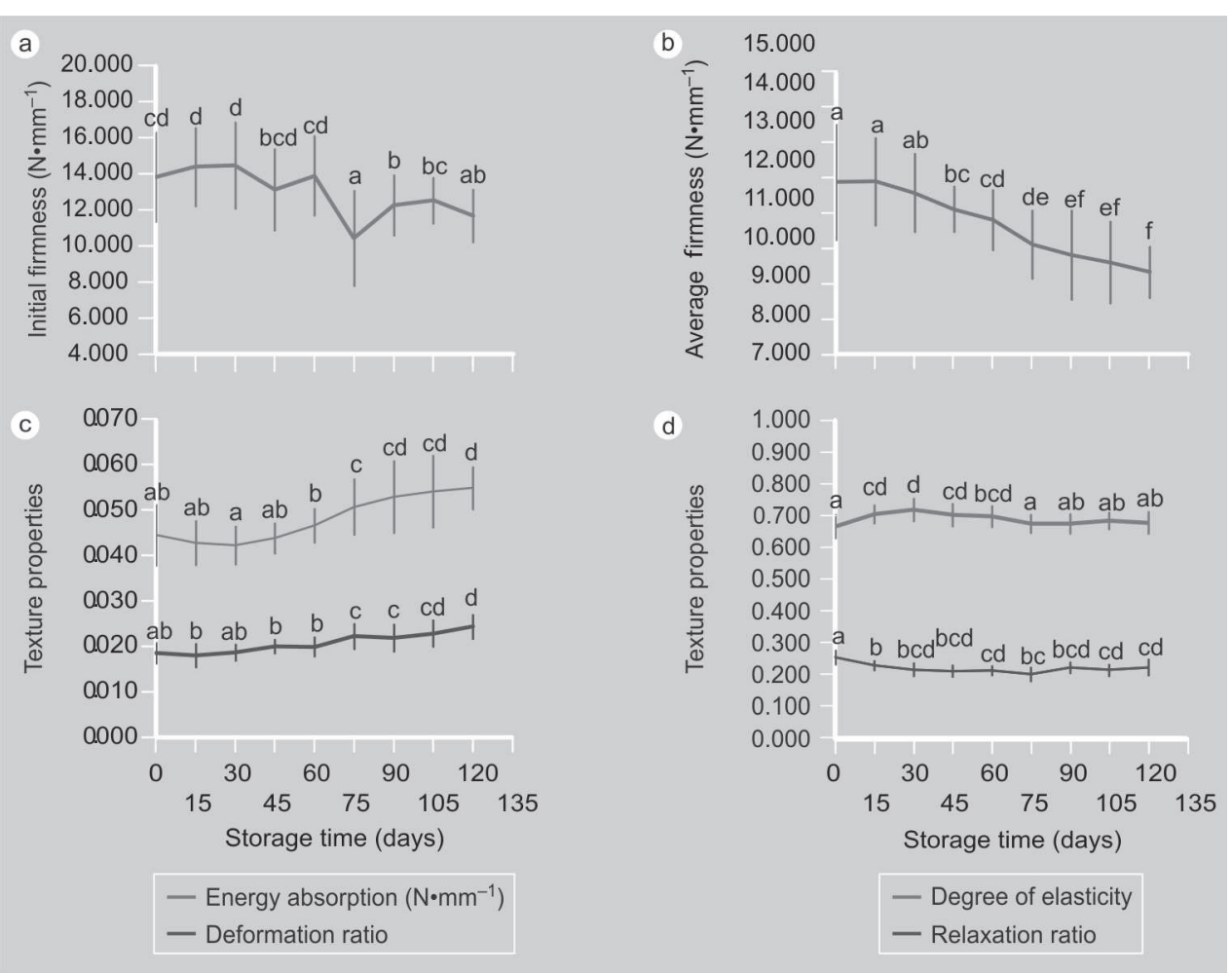

elasticity of the fruit decreased slightly during longer storage durations. The relaxation ratio also dropped slightly during storage, from 0.256 to 0.203 from the beginning of storage up until the 75 day point; then, it increased again to 0.224 after 120 days of storage. The relaxation ratio indicates the viscoelasticity behavior of the fruit and when this value approaches zero, it means the material is more elastic rather than viscous. The relaxation ratio, which approaches one, indicates that the fruit is a more viscous material. The pomelo fruit until 75 days of storage was more elastic even though the average firmness of the fruit decreased. This agrees with the results of Sirisomboon et al. [15] where the less firm Japanese pear also had a lower relaxation ratio (i.e., the less firm Japanese pear was more elastic/less viscous during ripening).

Although the pomelo is a citrus fruit containing juice sacs, it displays more elastic behavior rather than viscous behavior which is due to the thick, strong structure of the rind and lamella covers. These tightly cover the juice sacs such that the composite behaves as a solid material in which the juice of individual sacs cannot move freely. After 75 days of storage, the relaxation ratio slightly increased, which indicates that the viscous behavior increased slightly and the elasticity decreased.

\subsection{Changes in textural properties measured by the puncture test}

For the average force-deformation curve obtained using the puncture test on pomelos at different storage durations (figure 3), the resistance force of the lamella (the second peak) was averaged with the data of the flesh because the position of the lamella in each fruit was different. Therefore, the second peak in the average curve did not truly represent the resistance force of the lamella. Nevertheless, it could be seen from the slope of the force-deformation curve (from origin to the first peak) before the point of maximum force (first peak), which is indicative of the average firmness of the flavedo, that this textural property studied by the puncture test decreased with storage time.
Figure 2.

Change in textural properties of pomelo at different storage durations measured by the plate compression test. Data are mean values of 20 fruits. The error bars indicate the standard deviation of the samples. a to f: mean separation within columns by the LSD test $(P<0.05)$. Values with similar letters are not significantly different. 


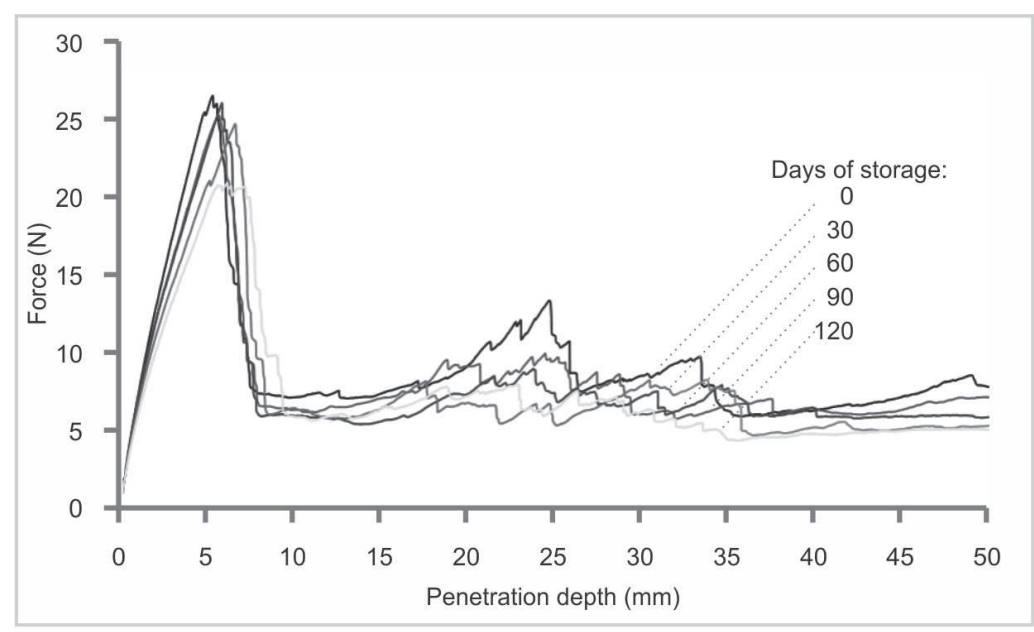

Figure 3.

Average force-time curve of the puncture test of pomelo at different storage durations. Samples of 18-20 fruit studied for each storage duration.
During the course of the puncture test, the probe was moved through the flavedo, albedo and lamella and into the flesh. When observing the change in textural properties based on the puncture test following differ-
Figure 4.

Change in textural properties of pomelo at different storage durations measured by the puncture test. Data are mean values of 20 fruits. The error bars indicate the standard deviation of the samples. a to $c$ : mean separation by the LSD test $(P<0.05)$. Values with similar letters are not significantly different. ing storage periods (figure 4), both the initial firmness and average firmness of the flavedo decreased with increasing storage duration (figure $4 a$ ). This indicates that the flavedo was less firm as the storage time increased. At the same time, the bio-yield force of the flavedo decreased while the bioyield distance remained unchanged ( $f i g$ ure $4 b$ ). The bio-yield distance did not vary appreciably. This indicates that the cells beneath the skin were weaker following storage. It could also be seen that the rupture force of the flavedo gradually decreased while the rupture distance gradually increased with increasing storage time (figure $4 \mathrm{c}$ ). This indicates that the flave do softened over time. When observing the change in penetrating force and penetrating energy of the albedo, neither parameter changed substantially over the course of the experiment (figure $4 d$ ), which indicates that the albedo texture remained essentially unchanged. Otherwise, the toughness, which is the energy

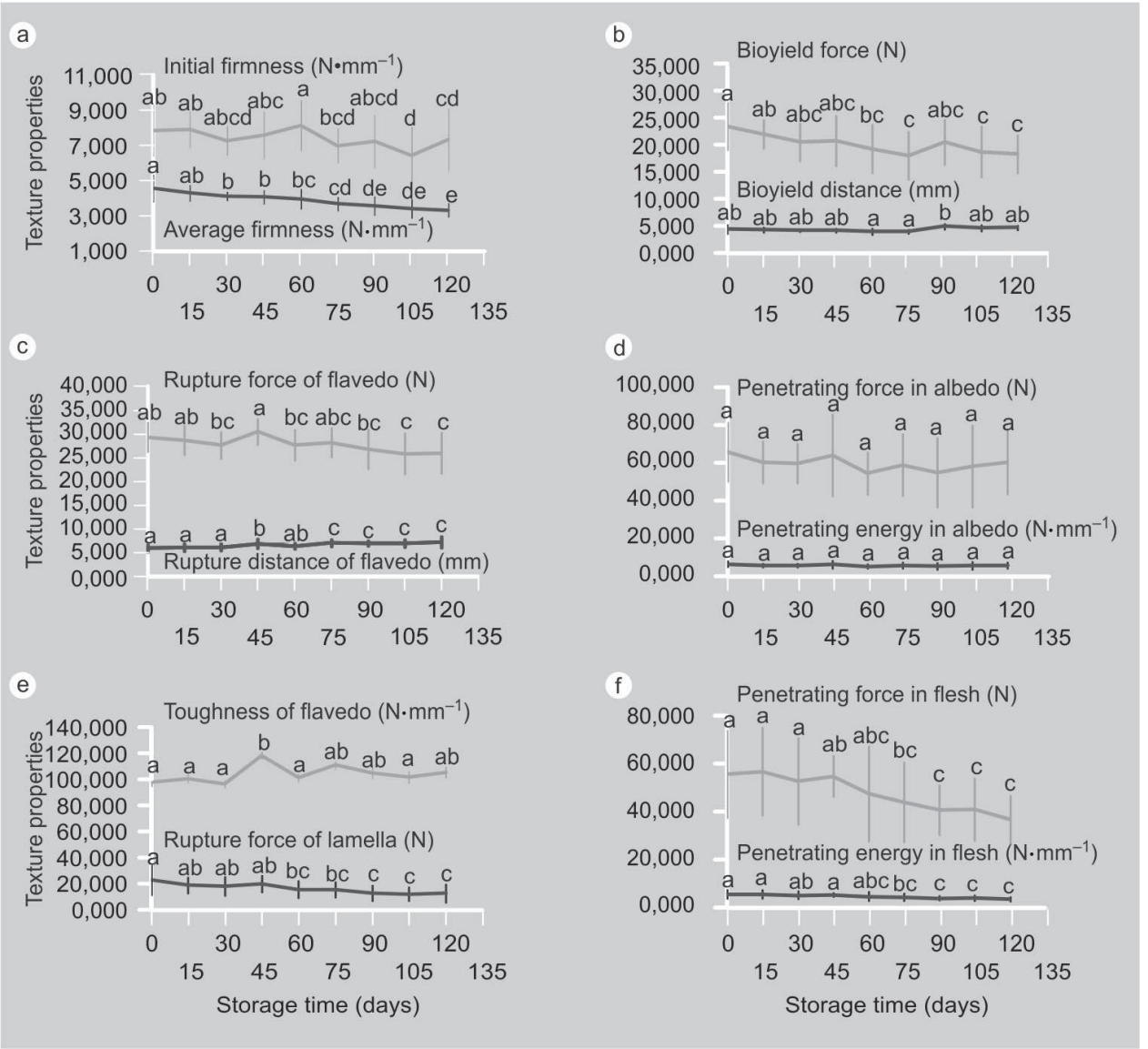


needed for rupture of the flavedo, did not vary appreciably, which indicates that the toughness of the flavedo was unaffected by storage time, and the rupture force of the lamella decreased with storage time, indicating the lamella had softened (figure 4e) Finally, the penetrating force and penetrating energy of the fruit flesh decreased with time (figure $4 f$ ). This means that the flesh became softer in texture following storage.

\subsection{Correlations among properties}

\subsubsection{Physical properties with CIE color and chemical properties}

The geometric mean diameter, average diameter and volume of pomelo correlated with each other and with fruit apparent density and weight. Weight did not correlate with apparent density, however (table III). The color properties, $L^{*}, a^{*}$ and $b^{*}$, did not correlate with physical properties (table III) but did correlate with each other (table IV). The chemical properties of the pomelo juice, i.e., soluble solids content (SSC), acidity (A) and their ratio [(SSC) / (A)] also did not correlate with physical properties (table III). However, (SSC) and [(SSC) / (A)] were correlated with $L^{*}, a^{*}$ and $b^{*}$ (table IV). This indicates that the change in flavor might be monitored over time simply by monitoring the change in color properties of the skin since this change is related to the biochemical processes occurring internally leading to the changes in properties related to taste. Soluble solids content and acidity did not correlate with each other (table $V$ ).

\subsubsection{Physical properties with textural properties}

The pomelo geometric mean diameter, weight, volume and average diameter, but not apparent density, correlated negatively with the deformation ratio from the plate compression test and the rupture distance of the flavedo from the puncture test (table III). This indicates that, when the size and mass of the fruit is larger, the strain decrease and the rupture distance at the puncture point decrease. This means that the overall strength of the fruit is higher with the size but its skin is weaker. The geometric mean diameter, volume, apparent density and average diameter, but not weight, correlated with penetrating force and penetrating energy in the albedo (table III). This indicates that the change in physical properties displayed a relationship with the change in texture of the albedo, which is understandable given that this is the most important part protecting the flesh when an external force is applied. The average diameter was found to correlate with the initial firmness and toughness of the flavedo (table III).

\subsubsection{Color properties with textural properties}

The $L^{*}, a^{*}$ and $b^{*}$ parameters correlated positively with the energy absorption and the deformation ratio of the whole fruit (i.e., from the plate compression test), but negatively with the average firmness, rupture force of the flavedo, penetrating force of the flavedo and penetrating energy in flesh from the puncture test (table IV). This indicates that, as the skin lightness $\left(L^{*}\right)$ increased, the greenness decreased ( $a^{*}$ increased and $a^{*}$ was a minus value) and yellowness increased ( $b^{*}$ was a plus value), the energy absorbed for permanent deformation and strain of the fruit increased (i.e., the fruit was more prone to applied force). However, when $L^{*}, a^{*}$ and $b^{*}$ increased, the firmness and strength of the flavedo (skin) decreased and the flesh was also softer. The $a^{*}$ parameter also correlated negatively with the average firmness from the plate compression test and with the toughness of the flavedo, penetrating force in the albedo, penetrating energy in the albedo and the rupture force of the lamella from the puncture test (table IV). This indicates that, when the greenness of the skin decreases, the firmness of the whole fruit decreases, as does the strength of the flavedo, albedo and lamella. The $L^{*}$ correlated negatively with average firmness from the plate compression test confirming that, when the skin lightens, the fruit firmness decreases. In comparison, in the case of the Carica papaya, no correlation existed between the texture strength and the internal color development over time [26]. 
Table III. Correlation coefficients between pomelo physical properties, color parameters, chemical properties and textural properties from the plate compression test and puncture test.

\begin{tabular}{|c|c|c|c|c|c|c|}
\hline \multirow[t]{2}{*}{ Properties } & & \multicolumn{5}{|c|}{ Physical properties } \\
\hline & & $\begin{array}{c}\text { Geometric mean } \\
\text { diameter }\end{array}$ & Weight & Volume & $\begin{array}{l}\text { Apparent } \\
\text { density }\end{array}$ & $\begin{array}{l}\text { Average } \\
\text { diameter }\end{array}$ \\
\hline \multirow[t]{5}{*}{ Physical properties } & Geometric mean diameter & 1.000 & - & - & - & - \\
\hline & Weight & 0.855 & 1.000 & - & - & - \\
\hline & Volume & 0.928 & 0.873 & 1.000 & - & - \\
\hline & Apparent density & -0.452 & -0.103 & -0.566 & 1.000 & \\
\hline & Average diameter & 0.774 & 0.749 & 0.778 & -0.351 & 1.000 \\
\hline \multirow[t]{3}{*}{ CIE color scale } & Lightness $L^{*}$ & -0.089 & -0.118 & -0.052 & -0.093 & -0.074 \\
\hline & Red-green value $a^{*}$ & 0.009 & -0.065 & 0.077 & -0.155 & 0.063 \\
\hline & Blue-yellow value $b^{*}$ & -0.036 & -0.104 & -0.038 & -0.095 & -0.043 \\
\hline \multirow[t]{3}{*}{ Chemical properties } & $\begin{array}{l}\text { Soluble solids content } \\
\text { (SSC) }\end{array}$ & 0.015 & -0.004 & -0.033 & 0.048 & -0.009 \\
\hline & Acidity (A) & -0.088 & -0.013 & -0.050 & 0.084 & -0.014 \\
\hline & {$[[(\mathrm{SSC}) /(\mathrm{A})]$ ratio } & -0.073 & -0.067 & -0.017 & -0.071 & -0.013 \\
\hline \multirow{6}{*}{$\begin{array}{l}\text { Textural properties } \\
\text { from plate compression } \\
\text { test }\end{array}$} & Initial firmness & 0.099 & 0.123 & 0.060 & 0.070 & 0.125 \\
\hline & Average firmness & 0.025 & 0.096 & -0.013 & 0.182 & 0.033 \\
\hline & Energy absorption & -0.095 & -0.173 & -0.068 & -0.152 & -0.102 \\
\hline & Degree of elasticity & -0.126 & -0.094 & -0.154 & 0.141 & -0.119 \\
\hline & Relaxation ratio & -0.075 & -0.018 & -0.087 & 0.147 & -0.056 \\
\hline & Deformation ratio & -0.375 & -0.459 & -0.340 & -0.061 & -0.424 \\
\hline \multirow{12}{*}{$\begin{array}{l}\text { Textural properties } \\
\text { from puncture test }\end{array}$} & Initial firmness of flavedo & 0.192 & 0.124 & 0.156 & -0.153 & 0.195 \\
\hline & $\begin{array}{l}\text { Average firmness of } \\
\text { flavedo }\end{array}$ & 0.108 & 0.154 & 0.059 & 0.128 & 0.113 \\
\hline & Bio-yield force & 0.012 & 0.067 & 0.022 & 0.055 & 0.071 \\
\hline & Bio-yield distance & -0.113 & -0.072 & -0.063 & 0.011 & -0.067 \\
\hline & Rupture force of flavedo & -0.128 & -0.074 & -0.152 & 0.181 & -0.148 \\
\hline & $\begin{array}{l}\text { Rupture distance of } \\
\text { flavedo }\end{array}$ & -0.274 & -0.260 & -0.230 & 0.039 & -0.289 \\
\hline & Toughness of flavedo & -0.181 & -0.168 & -0.167 & 0.051 & -0.197 \\
\hline & $\begin{array}{l}\text { Penetrating force in } \\
\text { albedo }\end{array}$ & -0.369 & -0.193 & -0.366 & 0.458 & -0.313 \\
\hline & $\begin{array}{l}\text { Penetrating energy in } \\
\text { albedo }\end{array}$ & -0.369 & -0.193 & -0.366 & 0.458 & -0.313 \\
\hline & Rupture force of lamella & 0.124 & 0.070 & 0.082 & -0.054 & 0.135 \\
\hline & Penetrating force in flesh & 0.134 & 0.110 & 0.087 & -0.007 & 0.095 \\
\hline & $\begin{array}{l}\text { Penetrating energy in } \\
\text { flesh }\end{array}$ & 0.134 & 0.110 & 0.087 & -0.007 & 0.095 \\
\hline \multicolumn{2}{|c|}{ Significant value of $R$ at confidence level of 0.99} & 0.194 & 0.195 & 0.194 & 0.194 & 0.194 \\
\hline \multicolumn{2}{|l|}{ Number of samples } & 178 & 177 & 178 & 178 & 178 \\
\hline
\end{tabular}

3.5.4. Chemical properties with textural properties

The fruit soluble solids content (SSC) correlated negatively with the deformation ratio from the plate compression test and positively with the bio-yield force, rupture force of the flavedo, rupture force of the lamella, penetrating force in flesh and penetrating energy in flesh from the puncture test (table V). This indicates that, when the soluble solids content of juice was higher, so was the fruit strength, the strength of the flavedo, lamella and the flesh. The acidity (A) 
Table IV. Correlation coefficients between pomelo color parameters, chemical properties and textural properties from the plate compression test and puncture test.

\begin{tabular}{|c|c|c|c|c|}
\hline \multirow[t]{2}{*}{ Properties } & & \multicolumn{3}{|c|}{ CIE color scale } \\
\hline & & Lightness $L^{*}$ & Red-green value $a^{*}$ & Blue-yellow value $b^{*}$ \\
\hline \multirow[t]{3}{*}{ CIE color scale } & Lightness $L^{*}$ & 1.000 & - & - \\
\hline & Red-green value $a^{*}$ & 0.754 & 1.000 & - \\
\hline & Blue- yellow value $b^{*}$ & 0.869 & 0.672 & 1.000 \\
\hline \multirow[t]{3}{*}{ Chemical properties } & Soluble solids content (SSC) & -0.270 & -0.452 & -0.233 \\
\hline & Acidity (A) & 0.078 & 0.156 & 0.022 \\
\hline & {$[[(\mathrm{SSC}) /(\mathrm{A})]$ ratio } & 0.348 & 0.556 & 0.320 \\
\hline \multirow{6}{*}{$\begin{array}{l}\text { Textural properties } \\
\text { from plate compression test }\end{array}$} & Initial firmness & -0.138 & -0.146 & -0.106 \\
\hline & Average firmness & -0.213 & -0.263 & -0.165 \\
\hline & Energy absorption & 0.255 & 0.291 & 0.245 \\
\hline & Degree of elasticity & -0.043 & -0.185 & -0.016 \\
\hline & Relaxation ratio & -0.123 & -0.085 & -0.082 \\
\hline & Deformation ratio & 0.284 & 0.279 & 0.217 \\
\hline \multirow{12}{*}{$\begin{array}{l}\text { Textural properties } \\
\text { from puncture test }\end{array}$} & Initial firmness of flavedo & -0.144 & -0.137 & -0.073 \\
\hline & Average firmness of flavedo & -0.507 & -0.431 & -0.379 \\
\hline & Bio-yield force & -0.271 & -0.161 & -0.259 \\
\hline & Bio-yield distance & 0.099 & 0.140 & 0.012 \\
\hline & Rupture force of flavedo & -0.409 & -0.453 & -0.380 \\
\hline & Rupture distance of flavedo & 0.159 & 0.047 & 0.020 \\
\hline & Toughness of flavedo & -0.137 & -0.221 & -0.199 \\
\hline & Penetrating force in albedo & -0.163 & -0.234 & -0.173 \\
\hline & Penetrating energy in albedo & -0.163 & -0.234 & -0.173 \\
\hline & Rupture force of lamella & -0.252 & -0.209 & -0.172 \\
\hline & Penetrating force in flesh & -0.286 & -0.315 & -0.238 \\
\hline & Penetrating energy in flesh & -0.286 & -0.315 & -0.238 \\
\hline \multicolumn{2}{|c|}{ Significant value of $R$ at confidence level of 0.99} & 0.195 & 0.195 & 0.195 \\
\hline \multicolumn{2}{|l|}{ Number of samples } & 177 & 177 & 177 \\
\hline
\end{tabular}

did not correlate with any textural properties, while the [(SSC) / (A)] correlated with the same textural properties as (SSC), but oppositely. This implies that, when the [(SSC) / (A)] increased, the strength of the fruit was lower and so too was the strength of the flavedo, lamella and the flesh. The [(SSC) / (A)] also correlated negatively with the average firmness of the flavedo from the compression test, confirming that the firmness of the fruit was less when the [(SSC)/ (A)] was higher. It was observed that the physical, color and juice chemical properties in our study did not have any relationship with the elastic or viscoelastic properties of the fruit.

\subsubsection{Correlation among textural properties}

In the results from the plate compression test, the energy absorption correlated negatively with the penetrating force in flesh and the penetrating energy in flesh (table VI), which indicates that, when the energy absorbed by the fruit was more, the flesh was softer. Otherwise, the relaxation ratio correlated only with the average firmness of the flavedo, indicating the importance of the flavedo in the viscoelasic property of the fruit. In the results from the puncture test, the rupture distance of the flavedo correlated negatively with the rupture force of the lamella (table VI), confirming 
Table V. Correlation coefficients between pomelo chemical properties and textural properties from the plate compression test and puncture test.

\begin{tabular}{|c|c|c|c|c|}
\hline \multirow[t]{2}{*}{ Properties } & & \multicolumn{3}{|c|}{ Chemical Properties } \\
\hline & & $\begin{array}{l}\text { Soluble solids content } \\
\text { (SSC) }\end{array}$ & $\begin{array}{l}\text { Acidity } \\
\text { (A) }\end{array}$ & $\begin{array}{l}{[(\mathrm{SSC}) /(\mathrm{A})]} \\
\text { ratio }\end{array}$ \\
\hline \multirow[t]{3}{*}{ Chemical properties } & Soluble solids content (SSC) & 1.000 & - & - \\
\hline & Acidity $(A)$ & -0.087 & 1.000 & - \\
\hline & {$[(\mathrm{SSC}) /(\mathrm{A})]$ ratio } & -0.864 & 0.419 & 1.000 \\
\hline \multirow{6}{*}{$\begin{array}{l}\text { Textural properties } \\
\text { from plate compression test }\end{array}$} & Initial firmness & 0.129 & -0.136 & -0.163 \\
\hline & Average firmness & 0.152 & -0.110 & -0.209 \\
\hline & Energy absorption & -0.124 & 0.075 & 0.161 \\
\hline & Degree of elasticity & 0.058 & -0.107 & -0.124 \\
\hline & Relaxation ratio & 0.100 & -0.085 & -0.143 \\
\hline & Deformation ratio & -0.259 & -0.063 & 0.235 \\
\hline \multirow{12}{*}{$\begin{array}{l}\text { Textural properties } \\
\text { from puncture test }\end{array}$} & Initial firmness of flavedo & 0.047 & 0.057 & 0.000 \\
\hline & Average firmness of flavedo & 0.189 & 0.098 & -0.192 \\
\hline & Bio-yield force & 0.239 & 0.010 & -0.199 \\
\hline & Bio-yield distance & 0.107 & -0.058 & -0.071 \\
\hline & Rupture force of flavedo & 0.246 & 0.153 & -0.210 \\
\hline & Rupture distance of flavedo & 0.007 & 0.039 & 0.022 \\
\hline & Toughness of flavedo & 0.154 & 0.108 & -0.104 \\
\hline & Penetrating force in albedo & 0.114 & -0.136 & -0.170 \\
\hline & Penetrating energy in albedo & 0.114 & -0.136 & -0.170 \\
\hline & Rupture force of lamella & 0.209 & -0.025 & -0.223 \\
\hline & Penetrating force in flesh & 0.350 & -0.089 & -0.331 \\
\hline & Penetrating energy in flesh & 0.350 & -0.089 & -0.331 \\
\hline \multicolumn{2}{|c|}{ Significant value of $R$ at confidence level of 0.99} & 0.194 & 0.194 & 0.194 \\
\hline \multicolumn{2}{|l|}{ Number of samples } & 178 & 178 & 178 \\
\hline
\end{tabular}

that, when the deformation of the flavedo before rupture, i.e., the stiffness of the flavedo, increased, the strength of the lamella decreased. The penetrating force in flesh and the penetrating energy in flesh also correlated positively with the bio-yield force, rupture force of the flavedo, toughness of the flavedo and rupture force of the lamella, indicating that the flesh softness changed with the softness of cells just beneath the skin, flavedo and lamella.

\section{Conclusion}

In our study, the physical, chemical and textural properties of the pomelo fruit (Citrus maxima or Citrus grandis cv. Kao Num Peung) were extensively evaluated over the course of a 4-month storage period. We found that the apparent density did not change significantly over time, while physical properties such as size, weight and volume changed only slightly. This might be due to the fact that the fruit was waxed before storage, preventing significant evaporation of water.

Color properties $\left(L^{*}, a^{*}, b^{*}\right)$ changed most significantly with storage. The lightness $\left(L^{*}\right)$ increased, greenness $\left(-a^{*}\right)$ decreased and the yellowness $\left(b^{*}\right)$ increased over time. However, the color did not change much during the initial 45 days of storage. The change in soluble solids content (\%Brix), acidity and the [soluble solids content / acidity] ratio suggested that pomelo fruit should not be stored for more than 75 days.

The firmness of the whole fruit decreased during storage. The firmness of the flavedo also decreased with the increase in storage, 


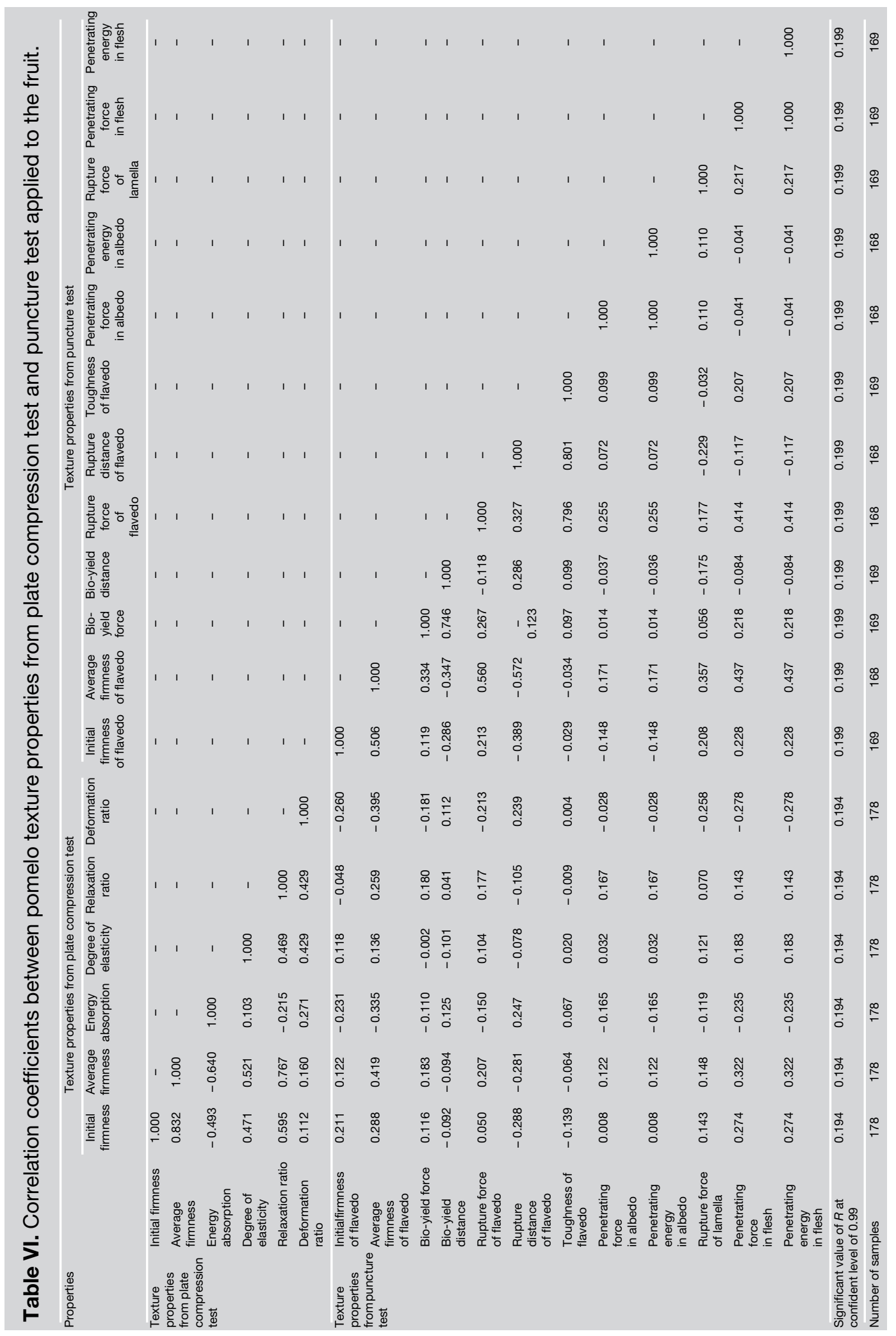


due to increased weakness in the cells beneath the fruit's outer skin. In addition, the flavedo was found to be softer, but tougher. The lamella and flesh were observed to soften over time, while the albedo showed no change in texture.

The correlation among physical, color, chemical and textural properties were subsequently assessed. Crucially, our results demonstrate that, amongst all the physical parameters studied here, the $a^{*}$ parameter (greenness, $R=-0.556$ ) correlates best with the chemical property the [soluble solids content / acidity] ratio, which is a recognized measurement of the consumer acceptability of the citrus fruit. This important result means that breeders and postharvest technologists as well as distributors, market agents, importers and exporters of pomelos have a non-destructive way of monitoring the taste characteristics of pomelos in storage. The $L^{*}$ and $a^{*}$ parameters also correlated well with the average firmness of the fruit and $L^{*}, a^{*}, b^{*}$ correlated with the flesh texture.

\section{Acknowledgments}

The authors gratefully acknowledge the financial support provided by the Thailand Research Fund and King Mongkut's Institute of Technology Ladkrabang under TRF-master research grants (Science and Technology) (MGR-WII505E070). The opinions expressed in this research article are the authors' alone.

\section{References}

[1] Magazin N., Gvozdenovic D., Keserovic Z. Milic B., Fruit quality of Granny smith apples picked at different harvest times and treated with 1-MCP, Fruits 65 (3) (2010) 191-197.

[2] Osuna-Garcia J A., Doyon G., SalazarGarcia S., Goenaga R., Gonzalez-Duran I.J.L., Effect of harvest date and ripening degree on quality and shelf life of Hass avocado in Mexico, Fruits 65 (6) (2010) 367-375.

[3] Patel P.R., Gol N.B., Rao T.V.R., Physiochemical changes in sunberry (Physalis minima L.) fruit during growth and ripening, Fruits 66 (1) (2011) 37-46.
[4] Zarei M., Azizi M., Bashir-Sadr Z., Evaluation of physicochemical characteristics of pomegranate (Punica granatum L.) fruit during ripening, Fruits 66 (2) (2011) 121-129.

[5] Ding P., Tee Y.K., Physicochemical characteristics of dabai (Canarium odontophyllum Miq.) fruit, Fruits 66 (1) (2011) 47-52.

[6] Teixeira G.H. de A., Durigan J.F., Storage of 'Palmer' mangoes in low-oxygen atmospheres, Fruits 66 (4) (2011) 279-289.

[7] Miller W.R., McDonald R.E., Postharvest quality of GA-treated Florida grapefruit after gamma irradiation with TBZ and storage, Postharvest Biol. Technol. 7 (3) (1996) 253-260.

[8] Tietel Z., Lewinsohn E., Fallik E., Porat R., Importance of storage temperatures in maintaining flavor and quality of mandarins, Postharvest Biol. Technol. 64 (1) (2012) 175-182.

[9] Lafuente M.T., Ballester A.R., Calejero J., González-Candelas L., Effect of high-temperature-conditioning treatments on quality, flavonoid composition and vitamin $\mathrm{C}$ of cold stored 'Fortune' mandarins, Food Chem. 128 (4) (2011) 1080-1086.

[10] Mayuoni L., Tietel Z., Patil B.S., Porat R., Does ethylene degreening affect internal quality of citrus fruit? Postharvest Biol. Technol. 62 (1) (2011) 50-58.

[11] Katsiferis T., Zogzas N., Karathanos V.T., Mechanical properties and structure of unripe oranges during processing of "spoon sweets", J. Food Eng. 89 (2) (2008) 149-155.

[12] Sirisomboon P., Theamprateep C., Physicochemical and textural properties of pomelo (Citrus maxima Merr. cv. Kao Nam Pueng) fruit at preharvest, postharvest and during the commercial harvest period, Philipp. Agric. Sci. (2012) 95 (1) 43-52.

[13] Pallottino F., Costa C., Menesatti P., Moresi M., Assessment of the mechanical properties of Tarocco orange fruit under parallel plate compression, J. Food Eng. 103 (2011) 308-316.

[14] Blahovec J., Paprštein F., Susceptibility of pear varieties to bruising, Postharvest Biol. Technol. 38 (2005) 231-238.

[15] Sirisomboon P., Tanaka M., Akinaga T., Kojima T., Evaluation of the textural properties of Japanese pear, J. Texture Stud. 31 (2000) 665-677.

[16] Sirisomboon P., Tanaka M., Fujita S., Kojima T., Relationship between the texture and pectin constituents of Japanese pear, J. Texture Stud. 31 (2000) 679-690. 
[17] Sirisomboon P., Pornchaloempong P., Instrumental textural properties of mango (cv. Nam Doc mai) at commercial harvesting time, Int. J. Food Prop. 14 (2011) 441-449.

[18] Jha S.K., Sethi S., Srivastav M., Dubey A.K., Sharma R.R., Samuel D.V.K., Singh A.K., Firmness characteristics of mango hybrids under ambient storage, J. Food Eng. 97 (2010) 208-212.

[19] Zamorano J.P., Alique R., Canet W., Mechanical parameters to assess quality changes in Cherimoya fruit, Z. Lebensm. Unters. Forsch. A 208 (1999) 125-129.

[20] Mohsenin N.N., Physical properties of plant and animal materials. Structure, physical characteristics and mechanical properties. 2nd revis. ed., Gordon Breach Sci. Publ., U.S.A., 1986, 981 p.

[21] Sirisomboon P., Kitchaiya P., Pholpho T., Mahuttanyavanitch W., Physical and mechanical properties of Jatropha curcas L. fruits, nuts and kernels, Biosyst. Eng. 97 (2007) 201-207.

[22] Anon., Titratable acidity 942.15, in: AOAC Official Methods of Analysis, 15th ed., AOAC, U.S.A., 1990.

[23] Steel R.G.D., Torrie J.H., Principles and procedures of statistics, A biometrical approach, 2nd ed., McGraw-Hill Book Co., Singap., 1980, $597 \mathrm{p}$.

[24] Baldwin E.A., Citrus fruit, in: Seymour G.B., Taylor J.E., Tucker G.A. (Eds.), Biochemistry of fruit ripening, Chapman and Hall, Lond., U.K., 1993, 122 p.

[25] Campbell B.L., Nelson R.G., Ebel R.C., Dozier W.A., Campbell J.H., Woods F.M., Mandarin market segments based on consumer sensory evaluations, J. Food Distrib. Res. 39 (2008) 43-55.

[26] Peleg M., Gómez Brito L., External color as a maturity index of papaya fruits, J. Food Sci. 39 (1974) 701-703.

\section{Evaluación de las propiedades físico-químicas y de textura de pomelos durante su almacenaje.}

Resumen - Introducción. Dada la duración del transporte y del almacenaje frecuentemente constatada, sería importante comprender cómo, con el tiempo, cambian las propiedades de los pomelos. Dicha información podría ser útil para evaluar el tiempo de almacenaje durante el cual las muestras conservan una calidad gustativa aceptable. A falta de datos disponibles en la literatura sobre el almacenaje del pomelo, estudiamos la variación de las propiedades físico-químicas y de la textura de este fruto, en un periodo de almacenaje de aproximadamente 4 meses. Material y métodos. Durante 4 meses de almacenaje, se evaluó el cambio de los componentes de propiedades físicas, químicas y de textura de los pomelos comerciales. También se evaluaron las correlaciones entre dichos componentes diversos. Resultados. Los parámetros de color $\left(L^{*}, a^{*}, b^{*}\right)$ variaron de manera significativa durante el almacenaje, pero no cambiaron mucho durante los primeros 45 días en almacenamiento. El cambio del contenido en sólidos solubles (SSC), de la acidez (A) y de la relación [(SSC) / (A)] sugirió que los pomelos no deberían almacenarse más de 75 días. Fundamentalmente, nuestro estudio demostró que el parámetro $a^{*}$ (enverdecimiento, $R=-0,556$ ) es el que mejor correlación tiene con la propiedad química "relación [(SSC) / (A)]" que es un índice reconocido de aceptabilidad de los frutos por el consumidor de cítricos. Esto significa que el índice de $a^{*}$ podría ser una técnica no destructiva que permite controlar las características del sabor de los pomelos durante su almacenaje. Dicho parámetro también tiene una buena correlación con la firmeza media del fruto y la textura de su carne. Conclusión. Esta información fundamental acerca del pomelo podría ser útil para los mejoradores, técnicos, así como para los distribuidores, comerciales, importadores y exportadores en cuanto a la manutención y el tratamiento industrial de los frutos después de su cosecha.

Tailandia / Citrus grandis / frutas / pomelo / almacenamiento / propiedades fisicoquímicas / textura / propiedades reológicas 